\title{
The failure of Virginia woolf's characterization in Mrs. Dalloway and to the lighthouse
}

\author{
Mushtaq Ahmed Kadhim Aldewan * \\ Department of 1st Teacher Class, University of Sumer College of Basic Education, Al-Rifa'i District, Iraq
}

\section{Keywords \\ Woman \\ Tradition \\ Mrs. Ramsay \\ Mrs. Dalloway \\ Lily Briscoe}

Received: 6 May 2020

Accepted: 16 October 2020

Published: 12 December 2020

\begin{abstract}
This paper aims to handle one of the troublesome and broadly dubious parts of Virginia Woolf's fiction, specifically, portrayal. Portrayal, as characterized by Martin Gray, is "how an essayist makes characters in a story to pull in or repulse our compassion" (Gray, 1992). For all the achievement and notoriety that Woolf has accomplished as a standout amongst the most noticeable English authors. As a scholarly commentator of a high bore, her books have been consistently an objective for rushes of extreme fundamental assaults. In his exposition "The Nature of Virginia Woolf", David Daiches specifies a portion of the charges against Woolf's fiction. An overview of the basic reactions to Woolf's books starting from the thirties to the nineties demonstrates the dependability of this conviction. This charge has progressed toward becoming almost a traditional pattern in Woolf's analysis. A short re-visitation of Ralph Freedman's case, is carried out in this study and useful insights for the scholars have been presented.
\end{abstract}

(C) 2020 The Author(s). Published by TAF Publishing

\section{INTRODUCTION}

Virginia Woolf has lived in a period in which the standard disguise is unsafe on ladies. While Woolf endeavours immaturity in an eminent condition that Virginia was not numb to standard disguise on ladies. She focused with respect to this issue through the arrangement, the most remarkable specific contraption of her time. There are sure ladies types in her books. Some of them yield the endorsements of custom; some of them are awkward with appears yet nonresponsive as well. Also, there are several ladies characters who limit the assents of custom. This assessment bases on three female characters in two books, To the Lighthouse and Mrs. Dalloway. Among these characters, Mrs. Ramsay handles the action the general populace views her justifying as a housewife. Mrs. Dalloway isn't content with her movement as a housewife, regardless; paying little psyche to her hesitance, paying little mind to all that she stays aware of necessities of civilization.

The most adored character of Woolf, Lily Briscoe, contra- dicts the endorsements of society. Most the remarks on Woolf's characters, expressing that "it is difficult to remarks on Woolf's characters, expressing that "it is difficult to keep up that here is an undying picture display" (Strachey, 1956). In Isabel Gamble assaults Woolf's characters and explains that we are not to search for any positive demonstration or distinct transgression that requests reparation" (Latham, 1970). In 1981, Carolyn Heilbrun called attention to that "the disappointment of portrayal is the expense of not doing what the world anticipated from an author" (Heilbrun, 1981). In 1988, Stephen Miko demands to portray Woolf's characters as voices" and includes that "it was troublesome for Virginia Woolf to make these voices, it appears to be much progressively troublesome for commentators to realize what to state about them" (Miko, 1988). In Fernald (1994) claims that Woolf makes an individual yet unspecific character" (Fernald, 1994). Impressions of this basic frame of mind broaden, about, to all Woolf's courageous women, who are generally thought little of and drawn nearer as

\footnotetext{
* corresponding author: Mushtaq Ahmed Kadhim Aldewan

†email: mushtaqaldewan@gmail.com
} 
irresolute, and inconsequential by generally pundits. She could only here and there depict a character that it was recollected a short time later on its own record (Forster, 2019). Rachel in The Voyage Out Bowlby (2016) is treated by Joanne Frye as "a pre-adult, reluctant, slippery and indistinct" and furthermore as "a character who can't be gotten a handle on or laid out" (Frye, 1980). Rhoda, who ends it all in The Waves (Miko, 1988), is portrayed by Stephen Mike as having neither a job nor a reliable arrangement of marks", and that "she shows up indeed, even to taunt the mimetic rule by her absence of being"(2019, 74 Miss La Trobe in Between the Acts (Strachey, 1956), is additionally assaulted by Christopher Ames as " restricted" and as "unmistakably removed from the maker" (Ames, 1991).

\section{The Problem Statement}

The contention and keeps on overwhelming society.' Explore and talk about. The war and its belongings were a long way from being done by June 1923; they were basically put out of psyche by the privileged societies so as to come back to a feeling of pre-war ordinariness. Moreover, the issues that caused the war despite everything saturate Mrs Dalloway's general public with an irrefutable reverberation. These issues over and over show themselves in Mrs Dalloway and her visitors and in spite of the fact that was coming from an assortment of components, the issues for London in 1923 stem to a great extent from shallow mentalities held in the public eye. Nonetheless, behind the triviality of an amazingly class-based London, there exist brief 'minutes' and unobtrusive signs that society perceives the issues, and that change the two has and will keep on coming.

The disposition held in the public eye before entering the war despite everything keeps on ruling Clarissa's life. Her last name, Dalloway, has ramifications of the word dillydally and 'hesitate' articulately portrays how she drives her life. She lets us know in her own inside monologue toward the start of the novel that "she had an enthusiasm for gloves" and "Bond Street entranced her" showing the realism that inundates her reality. Moreover, her verbal trades with characters are unavoidably loaded with falsities, for example, the note kept in touch with Peter Walsh in fiercely overstated language, "wonderful to see you", which comes up short on any genuineness. Her trade with Hugh Whitbread in the recreation centre by the administration structures is similarly bogus. Instead of tuning in to what Hugh Whitbread says she is "conscious of her cap". Hugh's depiction of Evelyn's proceeded with sickness in a similar section diverges from Clarissa's musings and further makes us mindful of her 'evident' triviality. Subside Walsh, albeit one-sided, remarks twice that Clarissa is "undependable". Her answer to Lady Brunton at her gathering that she was "consummately well" is similarly bogus and she just gives this answer since "Woman Brunton despised ailment in the spouses of politicians. "We are reminded all through the novel that "there was continually something cold in Clarissa" further recommending an absence of genuine empathy. The tale develops to Clarissa's gathering and the continuous flow in her own inward monologue all through the gathering centres around names and places of individuals as opposed to genuine human feeling. It is known that the lifetime risk of B.D. in relatives of a bipolar proband is $5-10 \%$ for first degree relatives and $40-70 \%$ for monozygotic co-twins (Cao et al., 2016).

When we reach Clarissa Dalloway's gathering, we are in no uncertainty that all Virginia Woolf's characters are in varying degrees setbacks of the class-based demeanour that keeps on ruling in Mrs Dalloway's post-Victorian London. Be that as it may, the focal point of the novel on Clarissa causes her to show up the most noticeably terrible influenced. Indeed, even before the gathering, her class-based triviality is made increasingly outright through the notice of "Masters, Ascot" and "Ranelagh", which are all regularly high society occasions. Her slant that "she didn't feel anything for the Albanians, or was it the Armenians? Yet, she cherished her roses" assists with recommending that she is truly as phoney as she shows up because of the differentiation between something that is globally powerful and a bundle of unimportant roses. The story centres around hues in the main depiction of Clarissa Dalloway, referencing "white", "blue-green" and "pink". The notice of what she looked like (particularly regarding hues) rather than concentrating on feeling or thought assists with representing Clarissa's triviality further. Early portrayals of Clarissa as "extremely upstanding" and "vivacious" reinforce our estimation towards a shallow, self-raised woman in light of the fact that an absence of genuine passionate depiction implies we can't picture her in an enthusiastic sense. Besides, her depiction is frequently given to the peruser in a somewhat carnal manner. By page four we hear that there is "a pinch of the fledgeling about her" and descriptive words, for example, "picked" and "saturated", which come up short on any human characteristics are utilized to portray her activities and propose that she is unfeeling. It seems that a subset of patients may develop a neuro progressive course associated with poor outcomes, such as suicide attempts, hospitalization, and functional and neurocognitive impairment. Cao et al. (2016) hence, Virginia's B.D. Symptoms appear to 
be strongly linked to her family background. Virginia's biological inheritance translated into the great risk of developing mental illness. Nevertheless, it could be argued that her disease would have been milder had she not been exposed to childhood traumatic experiences. Virginia Woolf was sexually abused by her half-siblings, George and Gerald Duckworth, for nine years (Williams, 2016).

\section{METHODOLOGY}

\section{Feminist Criticism in the Wilderness}

A short re-visitation of Ralph Freedman's case, cited in the presentation, that To the Lighthouse 'interprets the common strategies for fiction ... into symbolism which gets from the discernments and recollections of the heroes', will finish up the exposition. It was the expectation to break down the cycle delineated by Freedman, how the view of a character become symbolism. My supposition that was that the structure of the novel lays vigorously on a continuous flow which collaborates with the external world and view of it and that revelations are a noteworthy aspect of this structure. Contemplating the minutes when revelations happen yields a comprehension of the cycle and restricting the investigation to revelations identified with the most continuous picture explains the strategy. To the Lighthouse ends up being an extremely valuable case of this strategy and Freedman finds in Virginia Woolf a refined expressive writer: 'The melodious nature of To the Beacon lies in its interpretation of the common strategies for fiction, for example, character and activity - into symbolism which gets from the observations and recollections of the heroes' (Frye, 1980). This victory, nevertheless, doesn't extra Woolf's characters into the Lighthouse from the charge of the failure of depiction. It comes similar to the otherworldly idea of liberating oneself! Through craftsmanship. It is proposed to give a gleam of desire instead of keep up any heroic estimations. All through the story, the characters keep up a resounding frustration, and it is crazy to save them through this delegate win of Lily Briscoe. Thusly, to the extent the conventional techniques of examining fiction, Woolf's fearless ladies in Mrs Dalloway and To the Lighthouse to satisfy the wants for both the scrutinizes and the intellectuals. It is difficult to work out what they look like or what they will be, notwithstanding, in to the extent Woolf's philosophical, classy and ladies' dissident attitudes they express force and force that simply the extraordinary specialty of Virginia Woolf could present. Freedman's case is a state of flight for this exposition since it gets its technique from similar essential suppositions, the significance of symbolism and how it identifies with recognitions and memory. I will zero in on the discernments and how they associate with symbolism by zeroing in on the most incessant picture: The ocean. It will be drawn closer from three unique points, or, as I will call it, as having three distinct features: a physical, a profound and a symbolical one. These aspects are viewed as interfacing with revelations, breakthrough moments and vision in which the characters acknowledge significant things about themselves and the world. Freedman sees the 'occasions' from an alternate perspective than I will, yet in any case, perceives their noteworthiness in moulding inward insight (Fernald, 1994). Woolf probably portrayed as her way of thinking that behind the cotton fleece there is an example, completeness, which turns out to be quickly obvious in a snapshot of being. The view of the revelations, just as they need to 'clarify' them, is the thing that Woolf felt made her an essayist and she was profoundly worried about strategies for passing on the being just as the non-being (Woolf, 'Sketch' 81). Nonetheless, as Morris Beja brings up, while essentially critical to her work, Woolf, in contrast to Joyce, never developed a hypothesis legitimate about revelations; our comprehension of them must be gotten from parts in journals, expositions and, obviously, her fiction (Bojesen, 2018).

The essential striking truth about Mrs Dalloway and Mrs Ramsay is that they miss the mark on a great deal to end up vital narrative pictures like, for example, Maggi Tulliver of George Eliot's The Mill on The Floss, Elizabeth Bennett of Jane Austen's Pride and Prejudice, Tess of Thomas Hardy's Tess of the d'Urbervilles or Zeinab of Mohamed Hussein Heike's Zeinab and Hamida of Naguib Mahfouz's Midaq Alley. In light of everything, to condemn Mrs Dalloway and Mrs Ramsay to the extent the standard thought of the legend as "the primary character in a play, novel or record verse" (Gray, 1992), will provoke the end that Woolf misses the mark on the innovative power of portraying the human character. Both of them reveal clear physical and energetic below zero condition, and it is outlandish that they explain impressions about their characters like the legends referred to already. "Their friendliness and affectability", says M.C.Bradbrook," are spared in such an insightful vacuum." (Latham, 1970). The breakdown of recognized characteristics has achieved extended interior quality; in an extended withdrawal of the individual inside his own shell. This inside quality, chaos and anxiety has been moreover featured by the long strolls forward that the examination of cerebrum research has taken since the periods of Freud. Individuals are not wise as they are thought to be; their direct isn't guided and obliged by the perceptive rather it is vulnerable before the force lying secured significant inside the sub-insightful and the unaware (Tilak, 1984). 


\section{RESULTS \& DISCUSSION}

\section{Characters and Ideas}

Woolf's idea of life, as reflected in her articles and books is unmistakably impacted by the climate of disarray and vulnerability made by the First World War, which goes with by indisputable mental floats. In her paper " Present-day Fiction", Virginia conveys that "life isn't a development of gig lights evenly sifted through; life is a splendid crown; a semi-direct envelope including us from the most reliable starting phase of acumen beyond what many would consider possible" (Hawthorn, 1975). Life, along these lines, isn't considered as a progression of coordinated encounters, but instead as dispersed minutes and realities. For her, the truth is "something extremely inconsistent, entirely undependable-found out in a windy street, in a piece of paper in the road or in a daffodil in the sun" (Handley, 1994). This is the thing that truly shapes the stuff of Woolf's fiction. She doesn't endeavour to force a casing on the disordered unconstrained encounters of life. Despite what might be expected, she inclines toward that the writer stays detached and lets these disengaged pictures shape themselves, and admits: "I can make up circumstances yet I can't make up plots" (Bell, 1977). In "Present-day Fiction", she likewise addresses authors, inquiring them not to be subjugated by making a well-masterminded plot. She comments that " the correct stuff of fiction is something other than custom would have us trust it" (Wussow, 1994). Hence she assaults the customary strategies of moving toward life pursued She depicts the writers who demand on a plot to the detriment of life itself as " Bond Street tailors".

Searching inside and life, it appears, is a long way from being "this way". Analyze for a minute a common personality on a customary day. The brain gets a horde impressions-trifling, phenomenal, fleeting, or engraved with the sharpness of steel. From all sides they come, an ongoing shower of endless iotas; and as they fall, as they shape themselves into the life of Monday or Tuesday. So that if an essayist were a liberated individual and not a slave, in the event that he could compose what he picked, not what he should, on the off chance that he could put together his work with respect to his own inclination and not upon the show, there would be no plot, no satire, no disaster, no adoration intrigue or fiasco in the acknowledged style (Brownstein, 1994). The existence that both Mrs Dalloway and To the Lighthouse depict is, exceptionally, a manifestation of this idea of life. The writer presents life as differing and circumscribed whatever multifaceted nature this may show. About this life, Walter Allen says: "Her topic is a steady one, the scan for an example of significance in the transition of heap impres- sions. The trouble of life is diminished to the trouble of a riddle" (Woolf, 1925). Mrs. Ramsay things cover, where the writer tries' to delineate the outsider and the disorganized as could be allowed. The pursuer can't follow any noteworthy experience or any reasonable line of activity. The characters are, therefore, lost in a progression of detached circumstances, which don't enable their personalities to take shape or create. Their undertakings are never unquestionably set, and they have no genuine issue to battle against and comprehend. Jean Guipuest, in this sense, sees that Woolf's characters "have a distrustful perspective on reality and the denial of united world opinion" (Forster, 2019). Stephen Miko, similarly, writes: Vital to her work have been endeavours to recommend or even to make straightforward solidarity underneath amazing decent variety, normally depicted through euphoric minutes in which characters feel blended or lost-in a bigger reality (Miko, 1988).

In To the Lighthouse, Woolf additionally endeavours to encapsulate life in an unconstrained manner through an arbitrary progression of occasions, which seem indiscernible, pointless and flexible. The epic is, obviously, an expansion of the picture of life displayed in Mrs Dalloway. In spite of the fact that the content is isolated into three sections, the activity does not move in a direct manner or in a successive time conspire, and each part can be taken a gander at independently. Part I "The Window" covers the occasions of a typical solitary day for Mrs Ramsay and her companions on occasion on the Isle of Skye. Part II "Time Passes" discusses the crumbling that happens to the Ramsay house and the passing of three individuals from the family, including Mrs Ramsay herself. Part III "The Lighthouse" discusses the voyage to the beacon, which has been for quite some time deferred, and about the composition of Lily Briscoe.

These gathering developments, in any case, lead to the retreat of individual character and obstruct the normal allure of the champion. The voice of Mrs Ramsy accordingly dissolves in different voices furthermore, ends up unclear. That is the reason Helen Wussow stresses that "Woolf dissipates this agreeable universe of certain learning and substitutes one in which the subject is perplexingly variable" (Handley, 1994). The world depicted in the Lighthouse spreads indiscreetly among Mrs Ramsay and her visitors yet without genuine advancement. In the expressions of Raghukul Tilak, it is a world that is "profoundly empty, in light of false suppositions and causes the passing of the spirit" (Tilak, 1984) (Added to this, the characters that accumulate on the Isle of Skye have all the earmarks of being the result of a separated society. They don't have a solitary issue, even on their master. Every last one of them is in an 
assortment of perspectives, which are dependably none opposing. That is the reason when Lily Briscoe watches her illustration room window and hears what they state about Mrs.Ramsay, she remarks that the genuine contrasts are sufficient, very enough" and includes that "they're more likely than not been individuals who hated her without a doubt, individuals who thought her excessively beyond any doubt, excessively radical. How dreary, they would state, and the equivalent dependably. No one knew precisely what had happened to her"(173 In his contention about Woolf's characters.

Clarissa, along these lines, withdraws and what we have, as she herself concedes, is Mrs Richard Dalloway; an articulate feeling of loss of character. In her journal of $30 \mathrm{Au}$ gust 1923, Woolf says: " I uncover delightful surrenders behind my characters: I think this gives precisely what I need; humankind, silliness and profundity" (Bell, 1977) Mr Dalloway, one of these characters, never finds a passage through which she can get away from the obscurity of these caverns and come to light. In her book Becoming A Heroine. Finding out About Women in Fiction (Squier, 1981), Rachel Brownstein wholes up the life of Mrs Dalloway in the caverns dogged by Woolf, saying: Clarissa Dalloway, a spouse and mother, lives her most distinctive life in her lone creative energy. The recognition, recollections and reflections that happen there are her genuine associations with other individuals. Occasions and connections that may be depicted in a practical novel are subjected in the novel to the awareness that moves around (Heilbrun, 1981).

In To the Lighthouse, Woolf makes her strategy impeccable and takes the continuous flow account - the procedure to its most astounding pinnacle. In "A Sketch of the Past", she remarks on her technique for portrayal in this novel expressing: "I guess that I accomplished for myself what psychoanalysts accomplish for their patients. I communicated some exceptionally long felt and profoundly felt feeling." Woolf (1976) the book, which is considered by numerous faultfinders the best of her books, indicates how a customary day lives in the brains of Mrs Ramsay and her visitors. As the day they spend on the Isle of Skye unfurls, each character surrenders to the fiery laws of the brain, which work without request or soundness.

To a limited extent I "The Window", the longest segment of the novel. Nothing occurs aside from the impressions, fears and perceptions that follow from the connection of little inconsequential episodes identified with what Mrs. Ramsay does. The pursuer is taken from one memory to another, and snapshots of examination incite all through the entire story. T.E. Apter stresses that Woolf "shifts from story of character's emotions to an interpretation of musings, to a juxtaposition of thought and memory" (Woolf, 1986). Mrs. Ramsay, in specific, is dependably in a condition of consideration, and the smoothness of her character is furtherly disturbed by her alterable temperament. Jack Stewart, subsequently, clarifies that "in her consistent consideration of the light, which is the substance of the beacon, Mrs. Ramsay loses all feeling of self'(Stewart, 1977). Woolf herself asks: "How might she be able to help to be that way?" and includes: "She was regularly embarrassed about her claim decrepitude" (50).

Woolf's extreme interest in the mere portrayal of the characters' consciousness is wonderfully expressed by Rebecca Saunders, who maintains that "there exist, into the Lighthouse, portions of the text that cannot be positively designated as the consciousness of any single character, passages that I will term unclaimed consciousness" (Saunders, 1993). It is evident, however, that the delineation of the conscious and the sub-conscious detains any attempt to have a solid image of Mrs Ramsay. The chaotic experiences of the mind become more significant than the character of Mrs Ramsay. What adds to the difficulty of drawing a definite image of Mrs Ramsay, is that the reader needs to plunge into the pre-narrative levels of Woolf's consciousness, and to have access to the sensations and impressions floating there (Mwangi et al., 2016).

What makes this a pre-reading requirement is that Woolf draws largely on memories and experiences, which have been stored up from her own childhood and youth. The reader needs to know the life of Julia Stephen, Woolf's mother, whom Mrs Ramsay represents. "Until she wrote To the Lighthouse", says William Handley, "Woolf was obsessed by the presence of her mother, who had died thirty years earlier" (Handley, 1994). In view of this inwardness and this hidden past, Mrs. Ramsay, as a character, fails to present herself to the reader. It must not be understood, however, that the flood of consciousness is working with Mrs Ramsay only. Woolf diffuses it in the whole of To the Lighthouse, especial house, especially through the character of Lily Briscoe. Lily's mind never stops throwing images and scenes from the past and the present. This confuses her and impedes her artistic creation. To emphasize that Lily resumes the main concern of the novel; to dramatize the world of the mind. Woolf describes her, saying:

Positively she was losing cognizance of external things. Also, as she lost awareness of external things, and her name and her character and her appearance (140).

As though it isn't sufficient for Woolf's characters to endure the two chokings out variables of the creator's idea of life 
and her utilization of the continuous flow story - procedure, Woolf's women's activist approach is a third factor that adds to their exploitation. As a matter of fact, Woolf's composing has been seen as a piece of another talk that started to challenge the overwhelming talk of sexual orientation in the mid-twentieth century. Roger Webster, in this regard, contacts in an A Room of One's Own (Webster, 1996) "a point of takeoff for the investigation of lady's writing and the start of a women's activist analysis", and beliefs Woolf to be "a piece of a bigger development of ladies essayists who had received an explicitly female purpose of seeing as Katherine Mansfield, Rebecca West and Dorothy Richardson" (Webster, 1996).

In A Room of One's Own, Woolf makes man controlled society in charge of the debilitation and end of lady's character. She sees a characteristic slightness that keeps running in the veins of all ladies because of the verifiable persecution to which lady was oppressed in male-centric social orders. The title itself signifies that up! To the start of the nineteenth century, it was a fantasy for a lady to have her very own room.

It calls for monstrous valour and quality. That servers to clarify to a limited extent the need that ladies so regularly are to men. Also, it serves to clarify how anxious they are under analysis. For on the off chance that she starts to come clean, the figure in the mirror shrivels; his readiness forever is decreased (Brownstein, 1994).

As per Patricia Cramer, "the devastating of lady's inventiveness is a noteworthy worry in the entirety of Woolf's books" (Cramer, 1993). This, unmistakably, applies on both Mrs Dalloway and To the Lighthouse, where the courageous women bear clear signs of lady's long-enduring in male centrist social orders. They bear the weight of a lady's feeling of natural inadequacy manifested through a long history of man's mastery and oppression. Mrs Dalloway shows up as a lady of extreme restrictions. Her conduct uncovers clear detail and experience. Her feelings "were all superficially. Underneath, she was canny" (68). She isn't an individual who can go out on a limb and feels a misrepresented need for insurance and security. She doesn't wed the splendid and splendid Peter Walsh, with whom she is infatuated, and lean towards the relentless and unsurprising Richard Dalloway. She trusts that Richard can give her more security. She believes that without him, a figure of power, she may not have had the capacity to adapt to her inalienable inside fear and shortcoming:

There was the dread; the mind-boggling insufficiency. She probably died (164) Mrs Dalloway sees herself vulnerable to disintegration, and although she attempts to conquer her vulnerability by contact with others, her terror in confronting strong people is great. Susan Squier, in this sense, describes the long day we spend with Mrs Dalloway as "a long confrontation between the character and her fallibility and with the strength of other people to whom she can turn for care" (Squier, 1981). When Mrs Dalloway's sense of disintegration becomes acute, she prefers solitude in her room. She spends a long time in front of the mirror trying to assemble herself into one single definite person. Yet, the mirror does not save her, and she soon discovers that her overriding contradictions can never be resolved:

Mrs Dalloway, thus, admits that her integrated image in front of other people is a false one, that actually hides a deep sense of bankruptcy as a character. Jermy Hawthorne, therefore. that "she seems to see within herself aspects of her youth and immaturity, which do not necessarily combine to produce a unified identity" (Kenney, 1975). Mrs. Dalloway shows no interest in anything of value. "There was nothing picturesque about her", says Woolf, she never said anything especially clever" (68-69). She devotes her life to her daughter Elizabeth, but she fails to convince us that she has been fulfilling a satisfactory role as a mother. Her knowledge is shallow, and she takes no intelligent interest in life concerns. This is evident when she mixes Americans and Albanians, and when Woolf writes about her: (Woolf, 1976).

\section{The Bravery of Woman}

The courageous women of Mrs Dalloway (Woolf, 1925) and To the Beacon (Lilienfeld, 1977) are not exemptions, and they endure the destiny of different courageous women. Clarissa Dalloway, the focal character in the previous, is seen by Jermy Hawthorn as "made out of contrary parts" (Hawthorn, 1975). Mrs Ramsay, the courageous Woman of the last mentioned, is gotten by Mary Jacobus as a character who "shows herself in the novel as nonattendance" (Bowlby, 2016). Mrs Dalloway and To the Lighthouse are picked for the investigation introduced in this paper since they are the collections of the most productive years in Woolf's profession as an author. They have the stamp of the centre period of the continuous flow story method, which comes after the clear stories of The Voyage Out and Night and Day, and the preliminary accounts of The Waves, Between the Acts and Orlando. Through the characters of Clarissa Dalloway and Mrs Ramsay, the examination explores the charge of the disappointment of portrayal which, for over fifty years of Woolf's passing, is as yet running. Having harped for some time on the current of suppositions against Woolf's portrayal, let us move now to the critical 
inquiry that this examination looks to reply, to be specific, what are the explanations for this patent disappointment of Woolf's portrayal? In reality, in perspective on the plenitude of basic material on Woolf's fiction, drawing closer any subject identified with her speciality turns into a troublesome undertaking. Tony Inglis, here, states that "no English writer of the mid-twentieth century, with the exception of Forster and Lawerence, appear to be all the more exceptionally respected (Bowlby, 2016). However, this investigation is started out of the analyst's faith in that to endeavour a tasteful response to the question raised above is a remunerating educational work. Generally, pundits have been alluding to the issue, or expounding on the disappointment of some character without infiltrating profoundly and all together into the universe of Woolf's characters to reveal the underlying foundations of the issue. It should not be understood, however, that the research endeavours to dispel this charge rehearsed about Woolf's characters. On the contrary, the study embraces the belief that Woolf means her characters to be astonishingly insignificant (Cao et al., 2016).

\section{Death Versus Life}

Demise was an endeavour to convey, individuals feeling the inconceivability arriving at the middle, which, mysteriously, avoided them; closeness drew separated; delight blurred; one was distant from everyone else. There was a grasp in death... On the off chance that it was currently to bites the specks of dust were present to be generally cheerful, she had said to herself... Odd, unimaginable; she had never been so cheerful. It is wonderful, here, that Woolf herself has picked the method for death to get away from the male-centric signs of war, which she couldn't withstand. At the point when the First World War broke out, Woolf understood that man controlled society was still groundbreaking. By the episode of the Second World War, she totally lost confidence in lady's capacity to overcome the man-centric tyrant figure. Consequently, on 28 March 1941, Woolf finished her enduring by suffocating herself in a waterway close to her home, abandoning her cap and strolling stick on the bank. Carolyn Heilbrun remarks on this decision (Bojesen, 2018).

Woolf believed that life would begin again, but not that she would be part of it. Other life might begin again, at the beginning of a new civilization, but not here. She must have thought with a great logic about suicide. The battle with what she thought of as horrible side of the universe, the forces of madness seemed to her likely to be lost. She has done all she could on that behalf, but it must have seemed to her that it was too late: masculine behaviour, extreme to the point of madness, had taken over the world. She chose to end her life before the chance to make that decision for herself could be taken from her (Heilbrun, 1981). Mrs. Ramsay, into the Lighthouse, similarly suffers from Woolf's feminist ideas. Through her Woolf effects, a projection of the psychological illness that inflicts Woman in patriarchal societies. Additionally, we have recently reported that childhood trauma partly mediates the effect of family history on B.D. diagnosis (Jansen et al., 2016). It is noteworthy that sexual abuse was associated with B.D. in our study, but not with major depressive disorder.

In her essay "Thoughts on Peace in An Air Raid", Woolf attacks women who try to become figures of authority, describing them as "slaves who are trying to enslave" (Latham, 1970). This is exactly what we can say about Mrs Ramsay, who tends to exercise an authoritarian maternal role in a novel in which Virginia Woolf! as Jane Lilienfeld believes, "gave vent to the great anger and hurt that her relations with her mother had caused her"(Rice, 2018). Like Julia Stephen, Woolf's mom who passed on when Virginia was just thirteen years of age, Mrs Ramsay demands to assume a compelling overbearing job in the life of her family and that of all the general population around her. She is quick to draw towards her the lives of those looking for consideration and assurance. This is clear in the anxiety she shows to her visitors at the gathering, and to the youthful craftsman Lily Briscoe whom she gives pet names as "her little Brisk". Woolf imagines this look for a dictator job as a declaration of the mental subzero condition and as an endeavour to discharge since quite a while ago stifled sentiments of accommodation and oppression. It even decreases the job of both Julia Stephen and Mrs. Ramsay as moms of youthful youngsters who need grown-up consideration. In her article "A Sketch of the Past". Woolf says about her mom:

"Can I remember ever being alone with her for more than a few minutes? Someone was always interrupting. When I think of her spontaneously she is always in a room full of people" (Stewart, 1977). She also writes about Mrs Ramsay's attempts to attract people to her:

Furthermore, all things considered - all things considered (here obliviously she drew herself together, physically, the feeling of her own magnificence getting to be, as it did as such sometimes, present to her)- all things considered, she had not for the most part any Magnificence and friendliness, at that point, are Mrs Ramsay's weapons to pull in individuals, and furthermore to draw her broke down self together. The utilization of these weapons, in any case, means that Mrs Ramsay is as yet detained by man's tyrant past and 
that her persistent scan for adoration and profound respect is close to an endeavour to resist that innate past. However, this self-extension does not impact that end, for it is a projection of the issue instead of an unequivocal treatment. Joanne Frye communicates this importance when she expresses that the focal duality of positive extension of self and last disintegration of self is normal for Woolf's art" (Frye, 1980). The mirror in Mrs Ramsay's room is Woolf's declaration against her. All through her persistent looking into this mirror, the picture which Mrs Ramsay suffers to keep up before individuals vanishes and a littler, progressively divided one, shows up:

Susan Squier examines the mirror-experiences, intermittent in Woolf's fiction, and elucidates that Woolf's champions seem "disregarded, mortified, or deprived of full selfhood when going up against their picture in others' eyes. A similar encounter anticipates them when they take a gander at their pictures in the mirror" (Squier, 1981). Actually, Woolf does not enable her courageous women to create selfishness or self - sanctification. She mirrors this in her mindful recognition of the picture of Mrs Ramsay in the mirror. It is additionally communicated hypothetically when Woolf writes in her diary: At the point when the entryway closes on every one of us that evaporates.

\section{CONCLUSION}

Depicting Mrs Ramsay, William Bankes reflects, the event that it was her magnificence simply that one idea of, one must recollect the trembling thing, the living thing. Similarly, on the off chance that it is Virginia Woolf's vision of equity that one considers, one must recall the way toward judging. To talk about Woolf's "vision" of equity is deluding. It implies balance. Woolf's vision of equity is a responsive beat of judging. It is a characteristic strategy for truth. Woolf's legitimate way of thinking, social relations, and feel blend into a responsive outlook a cadence of seeing and imagining. In Woolfian terms, it is the "tune of Mrs Ramsay. In the way of talking of women's liberation, it is awareness-raising. To lawful scholars, it is the music of equity. Equity lies in the trustworthiness of the way toward judging. The function of the adjudicator is to gauge the abstract encounters of the gatherings before him on the "sizes of an endlessly responsive heart" 455 and feel his way to a goal that has the personality of conventional request and all-inclusiveness. However, it is grounded in logical experience. Can Woolf's law be refined to a considerable part? It is safe to say that anything is of changelessness scratched on James Ramsay's "tablets of unceasing shrewdness? "Woolf shows what they don't contain.

\section{LIMITATIONS AND RECOMMENDATIONS}

There is no perfect, theoretical, applied plan through which we can limitedly isolate our thought, our laws, and eventually our lives. It isn't, as Mr Ramsay considers, either the notes on the console of a piano or the letters of the letter set. It isn't Sir James Fitz james Stephen's systematized lawful composition. It isn't the Bill of Rights. Nor is it the laws of market conduct as present-day law and financial matters researchers would have it. None of these theoretical requesting gadgets is impartial, universal, or regular. There is no fairness. There is no general target legal vantage point. We just can't accomplish a general vantage purpose of judgment through a unique idea. However, that doesn't mean our appointed authorities can't make progress toward and acknowledge comprehensiveness. Our adjudicators can understand the general, in spite of the fact that they can't show up at all-inclusiveness through theoretical logic. Universality doesn't lie in an outside vantage point.

\section{REFERENCES}

Ames, C. (1991). The modernist canon narrative: Woolf's between the acts and joyce's" oxen of the sun". Twentieth Century Literature, 37(4), 390-404. doi:https://doi.org/10.2307/441653

Bell, A. O. (1977). The diary of virginia. London, UK: Hogarth Press.

Bojesen, E. (2018). Passive education. Educational Philosophy and Theory, 50(10), 928-935. doi:https://doi.org/10.1080/ 00131857.2016 .1200003

Bowlby, R. (2016). Virginia woolf. London, UK: Longman.

Brownstein, R. M. (1994). Becoming a heroine: Reading about women in novels. Cambridge, MA: Columbia University Press.

Cao, B., Passos, I. C., Mwangi, B., Bauer, I. E., Zunta-Soares, G. B., Kapczinski, F., \& Soares, J. C. (2016). Hippocampal volume and verbal memory performance in late-stage bipolar disorder. Journal of Psychiatric Research, 73, 102-107. doi:https:// doi.org/10.1016/j.jpsychires.2015.12.012

Cramer, P. (1993). Virginia woolf's matriarchal family of origins in between the acts. Twentieth Century Literature, 39(2), 166-184. doi:https://doi.org/10.2307/441837 
Fernald, A. (1994). A room of one's own, personal criticism, and the essay. Twentieth Century Literature, 40(2), 165-189. doi:https://doi.org/10.2307/441801

Forster, E. M. (2019). Virginia woolf. London, UK: Cambridge University Press.

Frye, J. S. (1980). The voyage out: Thematic tensions and narrative techniques. Twentieth Century Literature, 26(4), 402-423. doi:https://doi.org/10.2307/441452

Gray, M. (1992). A dictionary of literary. London, UK: York Handbooks.

Handley, W. R. (1994). The housemaid and the kitchen table: Incorporating the frame in to the lighthouse. Twentieth Century Literature, 40(1), 15-41. doi:https://doi.org/10.2307/441549

Hawthorn, J. (1975). Virginia Woolf's Mrs. Dalloway: A study in alienation. New York, NY: Chatto and Windus for Sussex University Press.

Heilbrun, C. G. (1981). Virginia woolf in her fifties. Twentieth Century Literature, 27(1), 16-33. doi:https://doi.org/10.2307/ 441083

Jansen, K., Cardoso, T., Fries, G., Branco, J., Silva, R., Kauer-Sant'Anna, M., ... Magalhaes, P. (2016). Childhood trauma, family history, and their association with mood disorders in early adulthood. Acta Psychiatrica Scandinavica, 134(4), 281-286. doi:https://doi.org/10.1111/acps.12551

Kenney, S. (1975). Two endings: Virginia woolfs suicide and between the acts. University of Toronto Quarterly, 44(4), 265-289. doi:https://doi.org/10.3138/utq.44.4.265

Latham, J. (1970). Critics on Virginia Woolf. London, UK: George Allen and Unwin, Ltd.

Lilienfeld, J. (1977). The deceptiveness of beauty: Mother love and mother hate in to the lighthouse. Twentieth Century Literature, 23(3), 345-376. doi:https://doi.org/10.2307/441262

Miko, S. J. (1988). Reflections on" the waves": Virginia woolf at the limits of her art. Criticism, 30(1), 63-90.

Mwangi, B., Wu, M.-J., Cao, B., Passos, I. C., Lavagnino, L., Keser, Z., ... Soares, J. C. (2016). Individualized prediction and clinical staging of bipolar disorders using neuroanatomical biomarkers. Biological Psychiatry: Cognitive Neuroscience and Neuroimaging, 1(2), 186-194. doi:https://doi.org/10.1016/j.bpsc.2016.01.001

Rice, T. J. (2018). Virginia woolf: A guide to research. London, UK: Routledge.

Saunders, R. (1993). Language, subject, self: Reading the style of" to the lighthouse". A Forum on Fiction, 26(2), 192-213. doi:https://doi.org/10.2307/1345687

Squier, S. (1981). Mirroring and mothering: Reflections on the mirror encounter metaphor in Virginia Woolf's works. Twentieth Century Literature, 27(3), 272-288. doi:https://doi.org/10.2307/441232

Stewart, J. F. (1977). Light in to the lighthouse. Twentieth Century Literature, 23(3), 377-389. doi:https://doi.org/10.2307/ 441263

Strachey, L. (1956). Virginia woolf and lytton strachey: Letters. London, UK: Hogarth Press.

Tilak, R. (1984). Virginia woolf: To the lighthouse: A critical study. New Delhi, India: Rama Press.

Webster, R. (1996). Studying literary theory: An introduction. London, UK: Arnold.

Williams, L. C. (2016). Virginia woolf's history of sexual victimization: A case study in light of current research. Psychology, 5(6), 1151-1164.

Woolf, V. (1925). Mrs. dalloway. London, UK: The Hogarth Press.

Woolf, V. (1976). Virginia woolf: Moments of being: Unpublished autobiographical writings. London, UK: Harcourt Brace Jovanovich.

Woolf, V. (1986). The essays of virginia woolf. London, UK: The Hogarth Press.

Wussow, H. (1994). Virginia woolf and the problematic nature of the photographic image. Twentieth Century Literature, 40(1), 1-14. doi:https://doi.org/10.2307/441548 